\title{
Kajian Geofisika dan Geokimia Mangan di Desa Oetalus Kabupaten TTU
}

\author{
Regina Seran dan Eduardus Edi \\ Jurusan Kimia, Fakultas Pertanian, Universitas Timor, Kefamenanu \\ *Email: reginaseran@gmail.com
}

\begin{abstract}
Manganese ore is a mineral that is widely found in TTU district. The manganese mining process in Oetalus-TTU is still traditionally carried out by the community without knowing the distribution pattern of manganese ore. The selling price of manganese is classified as low because there is no information to the public about the quality of manganese in TTU. Therefore, this research was conducted to geoelectrically identify manganese distribution in Oetalus and perform geochemical characterization to determine the characteristics of manganese minerals. The method used to identify the spread of manganese is the geoelectric resistivity method of the Schlumberger configuration. This method is done by inducing an electric current to the earth through 2 current electrodes, then measuring the potential difference so that the apparent resistivity price will be obtained based on the electrode arrangement. The measured apparent resistivity value is influenced by the difference in the resistivity value of each subsurface rock layer. The tool used for geoelectric data collection is a set of OYO MCOHM-EL model 2119 resistivity meters. The geochemical characterization method uses XRF to determine the elemental composition and XRD to determine the type of manganese minerals. Based on the results of the study, the range of manganese resistivity values in Oetalus was 9-30 $\Omega \mathrm{m}$ with an estimated layer depth of 1-20 meters. Analysis using XRF obtained the elemental composition of manganese of $94.2 \%$. The manganese content in Oetalus is very potential and economical to be mined, because the economic average grade of manganese ore is $45 \%$. Analysis using XRD obtained that the type of manganese mineral in Oetalus is pyrolusite $\left(\mathrm{MnO}_{2}\right)$.
\end{abstract}

Keywords : Manganese, geoelectric resistivity, geochemistry.

\section{ABSTRAK}

Bijih mangan merupakan bahan galian yang banyak terdapat di kabupaten TTU. Proses penambangan mangan di desa Oetalus-TTU hingga saat ini masih dilakukan secara tradisional oleh masyarakat tanpa mengetahui pola penyebaran bijih mangan. Harga jual mangan pun tergolong rendah karena tidak ada informasi kepada masyarakat mengenai kualitas mangan yang ada di TTU. Oleh karena itu, penelitian ini dilakukan untuk identifikasi penyebaran mangan di lokasi penelitian desa Oetalus secara geolistrik dan melakukan karakterisasi secara geokimia untuk mengetahui karakteristik mineral mangan. Metode yang digunakan untuk identifikasi penyebaran mangan adalah metode geolistrik tahanan jenis konfigurasi schlumberger. Metode ini dilakukan dengan cara menginduksikan arus listrik ke bumi melalui 2 buah elektroda arus, kemudian diukur beda potensial maka akan diperoleh harga tahanan jenis semu berdasarkan susunan elektroda. Nilai tahanan jenis semu yang terukur dipengaruhi oleh adanya perbedaan nilai tahanan jenis setiap lapisan batuan bawah permukaan. Alat yang digunakan untuk pengambilan data geolistrik adalah 1 set resistivitymeter OYO MCOHM-EL model 2119. Metode karakterisasi secara geokimia menggunakan XRF untuk mengetahui komposisi unsur dan XRD untuk mengetahui jenis mineral mangan. Berdasarkan hasil penelitian diperoleh kisaran nilai tahanan jenis mangan di Oetalus yaitu 9-30 $\Omega \mathrm{m}$ dengan kedalaman lapisan diduga antara 1-20 meter. Analisis menggunakan XRF diperoleh komposisi unsur mangan sebesar 94,2\%. Kadar mangan di oetalus ini sangat potensial dan ekonomis untuk ditambang, karena kadar rata-rata ekonomis bijih mangan adalah $45 \%$. Analisis menggunakan XRD diperoleh jenis mineral mangan di Oetalus adalah pyrolusite $\left(\mathrm{MnO}_{2}\right)$.

Kata kunci: Mangan, geolistrik tahanan jenis, geokimia 


\section{PENDAHULUAN}

Bijih mangan merupakan salah satu bahan galian yang penggunaannya sangat besar dan banyak terdapat di NTT. Bijih mangan mengandung senyawa oksida dengan kadar yang bervariasi di setiap daerah. Mineral-mineral yang terkandung di dalam bijih mangan antara lain pyrolusite, manganite, psilomelane, hausmannite, rhodokrosite, rhodonite ${ }^{[1]}$. Bijih mangan merupakan salah satu unsur yang paling banyak terdapat di dalam kerak bumi dan berwarna hitam kelabu. Bijih mangan memiliki banyak kegunaan antara lain sebagai campuran pembuatan besi baja, bahan pembuatan ferro mangan dan lain lain. Bijih mangan juga berpotensi untuk dikembangkan sebagai bahan industri baterai ${ }^{[2]}$.

Tambang mangan di NTT banyak ditemui di Kabupaten Kupang, Manggarai, Belu, Timor Tengah Selatan dan Timor Tengah Utara (TTU). Mangan di TTU sudah ditambang sejak tahun 2011 tetapi masih menggunakan cara tradisional. Pada umumnya, mangan diambil oleh masyarakat dengan melakukan penggalian kemudian langsung dijual dalam bentuk mentah (raw material) sehingga harga jualnya sangat rendah. Masyarakat menambang mangan secara gali pilih karena sifat penyebaran endapan mangan di TTU secara acak dan tidak merata. Pengolahan mangan di Indonesia masih belum banyak dilakukan.

Penyelidikan secara geolistrik perlu dilakukan untuk mengidentifikasi penyebaran bijih mangan sehingga tidak perlu dilakukan sistem gali pilih di tempat yang tidak terdapat bijih mangan. Penyelidikan geokimia organik yang merupakan parameter baru belum banyak dilakukan sehingga informasi mengenai komposisi unsur, jenis mineral serta tingkat kematangan mangan belum bisa dilaporkan untuk meningkatkan harga jual bijih mangan di TTU. Oleh karena itu, perlu dilakukan karakterisasi geokimia organik untuk mengetahui komposisi kimia mangan, jenis mineral, dan kualitas mangan.

Logam mangan berada pada urutan ke-12 dalam hal kelimpahan pada kerak bumi dengan rata-rata $0,1 \%$ serta berada pada urutan ke-4 dari segi jumlah konsumsi setelah besi, aluminum dan tembaga. Konsumsi mangan secara global sekitar $92 \%$ berkaitan langsung dengan industri baja dan sisanya digunakan dalam aplikasi nir besi seperti baterai sel kering, bahan pewarna dan industri kimia lainnya ${ }^{[3]}$.

Bijih mangan yang utama adalah pirolusit dan psilomelan, yang mempunyai komposisi oksida dan terbentuk dalam cebakan sedimenter dan residu. Mangan mempunyai warna abu-abu dengan kilap metalik sampai sub metalik, kekerasan 2-6 skala Mosh, berat jenis $4,8 \mathrm{~N} / \mathrm{m}^{3}$, massif, reniform, botriodal, stalaktit, serta kadang-kadang berstruktur fibrous dan radial. Mangan berkomposisi oksida lainnya namun berperan bukan sebagai mineral utama dalam cebakan bijih adalah bauxite, manganit, hausmanit, dan lithiofori, sedangkan berkomposisi karbonat adalah rhodokrosit, serta rhodonit yang berkomposisi silika ${ }^{[4]}$.

Tabel 1. Komposisi Mangan ${ }^{[5]}$

\begin{tabular}{lllc}
\multicolumn{3}{c}{ Tabel 1. Komposisi Mangan } \\
\hline No & \multicolumn{1}{c}{ Mineral } & \multicolumn{1}{c}{ Komposisi } & \%Komposisi Mn \\
\hline 1 & Bementite & $\mathrm{Mn}_{5} \mathrm{Si}_{6} \mathrm{O}_{15}(\mathrm{OH})_{10}$ & 43,2 \\
2 & Braunit & $\mathrm{Mn}_{2} \mathrm{Mn}_{6} \mathrm{SiO}_{12}$ & 66,6 \\
3 & Cryptomelan & $\mathrm{KMn}_{5} \mathrm{O}_{16}$ & 59,8 \\
4 & Franklinit & $\left(\mathrm{Fe}, \mathrm{Zn}_{2} \mathrm{Mn}\right) \mathrm{O}(\mathrm{Fe}, \mathrm{Mn})_{2} \mathrm{O}_{2}$ & $10-20$ \\
5 & Haussmannit & $\mathrm{Mn}_{3} \mathrm{O}_{4}$ & 72,0 \\
6 & Manganit & $\mathrm{Mn}_{2} \mathrm{O}_{3} \mathrm{H}_{2} \mathrm{O}$ & 62,5 \\
7 & Romanechit & $\mathrm{BaMn}_{5} \mathrm{O}_{16}(\mathrm{OH})_{4}$ & 51,17 \\
8 & Pyrolusit & $\mathrm{MnO}_{2}$ & 63,2 \\
9 & Rhodochrisit & $\mathrm{MnCO}_{3}$ & 47,8 \\
10 & Rhodonit & $\mathrm{MnSiO}_{3}$ & 41,9 \\
\hline
\end{tabular}


Mineral mangan dan paduannya merupakan logam strategis yang penting dalam bidang industri. Aplikasi mangan paling banyak digunakan dalam produksi baja, pupuk, baterai sel kering, cat dan bahan kimia lainnya. Seiring meningkatnya kebutuhan akan baja, kebutuhan akan mangan pun meningkat. Salah satu ferroalloy yang banyak digunakan dalam pembuatan baja adalah feromangan. Mangan ditambahkan kedalam baja agar baja menjadi lebih keras, memiliki keuletan sehingga tidak mudah patah ${ }^{[6]}$.

\section{Metode Geolistrik Tahanan Jenis}

Metode geofisika merupakan metode yang bisa digunakan untuk menduga jenis litologi, kedalaman dan struktur lapisan batuan di bawah permukaan tanah. Metode geofisika terbagi atas dua yaitu yang bersifat statis dan dinamis. Metode Geolistrik adalah salah satu metode geofisika yang sifatnya dinamis karena harus diberikan perlakuan terhadap lapisan batuan, sehingga bisa menduga jenis litologi dari respon yang terjadi ${ }^{[7]}$. Survei geolistrik menggunakan metode tahanan jenis (resistivity) dilakukan dengan cara menginduksikan energi listrik ke bumi kemudian diamati pengaruhnya terhadap lapisan batuan yang dilaluinya. Ada beberapa konfigurasi elektroda dalam pengukuran metode tahanan jenis yaitu konfigurasi Wenner, Konfigurasi dipole-dipole, dan konfigurasi Schlumberger ${ }^{[8]}$. Konfigurasi yang digunakan dalam penelitian ini adalah konfigurasi Schlumberger. Pengukuran geolistrik dilakukan untuk mengetahui variasi harga tahanan jenis semu batuan bawah permukaan. Arus listrik diinjeksikan ke dalam bumi melalui 2 buah elektroda arus, kemudian diukur beda potensial maka akan diperoleh harga tahanan jenis semu berdasarkan susunan elektroda. Nilai tahanan jenis semu yang terukur dipengaruhi oleh adanya perbedaan nilai tahanan jenis setiap lapisan batuan bawah permukaan.

Pada konfigurasi Schlumberger idealnya jarak MN dibuat sekecil mungkin, sehingga jarak MN secara teoritis tidak berubah. Tetap karena keterbatasan kepekaan alat ukur, maka ketika jarak $\mathrm{AB}$ sudah relatif besar maka jarak $\mathrm{MN}$ hendaknya diubah. Perubahan jarak $\mathrm{MN}$ hendaknya tidak lebih besar dari $1 / 5$ jarak $\mathrm{AB}{ }^{[7]}$.

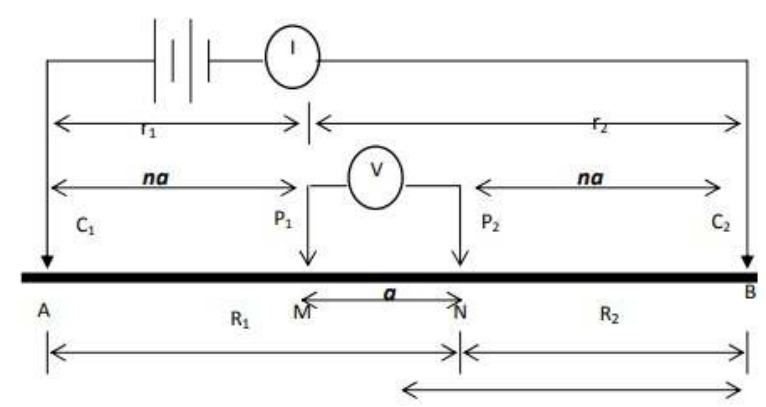

Gambar 1. Susunan elektroda konfigurasi Schlumberger

Untuk menghitung tahanan jenis semu, diperlukan suatu bilangan faktor geometri $(K)$ yang bergantung pada jenis konfigurasi, jarak $A B / 2$ dan $M N / 2$. Perhitungan konstanta $K$ untuk konfigurasi Schlumberger berdasarkan rumus:

$$
K=\pi \frac{\left((A B / 2)^{2}-(M N / 2)^{2}\right)}{M N}
$$

dimana $K$ adalah faktor geometri, $A B$ adalah jarak antara elektroda arus dan $M N$ adalah jarak elektroda potensial. Sehingga tahanan jenis semu $\left(\rho_{a}\right)$ adalah 


$$
\rho_{a}=K \frac{V}{I}
$$

dengan $\mathrm{V}$ adalah beda potensial dan I adalah arus listrik.

Penentuan tahanan jenis mangan menggunakan metode geolisrik yang telah dilakukan oleh Wirayuda diperoleh nilai resisitivitas mangan adalah 10-14 ohmmeter ${ }^{[9]}$. Pada penelitian berskala laboratorium mendapatkan kesimpulan bahwa kisaran nilai tahanan jenis mangan di kabupaten TTU yaitu antara $1 \Omega \mathrm{m}-32,5 \Omega \mathrm{m}^{[10]}$. Selain itu, menurut penelitian Hakim [11] diperoleh simpulan berdasarkan hasil penampang resistivitas 2D untuk setiap lintasan menunjukkan adanya anomali resistivitas rendah $(<5 \Omega \mathrm{m})$ yang diduga sebagai daerah keterdapatan mineral mangan. Nilai resistivitas $0,61-40 \Omega \mathrm{m}$ diasumsikan sebagai batu lempung karbonatan yang merupakan lingkungan terjadinya proses mineralisasi mangan.

\section{Metode Geokimia}

Data mineralogi dan komposisi kimia bijih mangan dapat digunakan untuk menginterpretasi genesis pembentukkan dan rekonstruksi model pengendapannya ${ }^{[12]}$. Hasil uji batu mangan (sebagai Mn) berupa pengujian produk batu mangan sesuai standar nasional industri dari perusahaan-perusahaan di jawa timur maupun dari perorangan diperoleh kadar mangan yang bervariasi. Dari 117 contoh uji didapat Kadar dibawah 10\% $(0,12 \%$ sampai $5,95 \%)$ ada 15 contoh. Kadar antara kadar antara $10 \%$ sampai $20 \%$ (10,28\% sampai 19,97\%) ada 15 contoh. Kadar antara 30\% sampai 40\% (30,34\% sampai $39,84 \%)$ ada 30 contoh. Kadar antara 40\% sampai 50\% (40,12\% sampai 49,92\%) ada 29 contoh. Kadar diatas 50\% (50,14\% sampai 53,64\%) ada 8 contoh. Yang paling banyak adalah kadar antara $20 \%$ sampai $50 \%{ }^{[13]}$.

Penelitian geokimia di NTT pernah dilakukan di kabupaten TTS dan kabupaten Belu. Menurut Naiola ${ }^{[14]}$ memperoleh hasil endapan mangan di Supul-TTS terbagi atas dua jenis. Jenis yang pertama adalah berupa nodul yang jenis mineralnya adalah manganit yang berasosiasi dengan limonit. Kadarnya adalah 44,10\% sedangkan kadar yang disajikan dalam bentuk oksida sebagai presentase berat $\mathrm{MnO}$ adalah 56,93\%. Jenis endapan mangan yang kedua adalah endapan mangan berlapis dengan jenis mineralnya adalah manganit dan pirolusit yang berasosiasi dengan Hydrous Iron Oxides, silika dan limonit. Hasil analisa kimia menunjukkan kadar Mn adalah 63,74\% sampai 66,43\%, kadar yang disajikan dalam bentuk oksida sebagai presentase berat $\mathrm{MnO}$ adalah 82,30\% sampai 85,77\%.

Da Costa ${ }^{[15]}$ juga melakukan penelitian di kabupaten Belu mendapatkan hasil endapan mangan terdiri dari dua jenis. Jenis yang pertama berupa nodul, jenis mineralnya adalah pirolusit dengan kadar Mn sebagai persentase berat $\mathrm{MnO}$ adalah 69,42\%. Jenis kedua adalah endapan mangan berlapis, mineralnya adalah manganit dengan kadar Mn sebagai persentase berat $\mathrm{MnO}$ adalah $67,66 \%$. Unsur besi hadir dalam persentase sangat kecil yaitu $0,36 \%$ pada mangan berlapis dan 1,34 pada mangan nodul dengan perbandingan $\mathrm{Fe} / \mathrm{Mn}$ sangat kecil $0,47 \%$ pada mangan berlapis dan $1,73 \%$ pada mangan nodul yang merupakan satu indikasi endapan sedimenter.

\section{METODE}

Penelitian ini dimulai dengan survey lokasi penelitian, pengambilan data geolistrik dan pengolahan data menggunakan program Res2dinv, serta pengambilan sampel di beberapa titik di lokasi penelitian untuk karakterisasi secara geokimia menggunakan XRF dan XRD. Pengambilan data geolistrik dilakukan di sekitar titik yang terdapat singkapan mangan. Alat yang digunakan untuk pengambilan data geolistrik adalah 1 set resistivitymeter Oyo 
McOHM-EL Model 2119, sumber tegangan (accu), GPS, kertas, pulpen dan labtop. Pengambilan data geolistrik ini menggunakan konfigurasi Shlumberger. Pada konfigurasi Shlumberger digunakan 2 buah elektroda arus $\left(\mathrm{C}_{1}\right.$ dan $\left.\mathrm{C}_{2}\right)$ dan 2 buah elektroda potensial $\left(\mathrm{P}_{1}\right.$ dan $\left.\mathrm{P}_{2}\right)$. Susunan elektroda seperti Gambar 1.

Data yang terukur berupa data Arus listrik (I) dan Beda potensial (V) kemudian dihitung nilai hambatan $(\mathrm{R})$, Faktor Geometri $(\mathrm{K})$ dan tahanan jenis semu $\left(\rho_{\mathrm{s}}\right)$. Data-data yang diperoleh pada setiap lintasan pengukuran ini dijadikan sebagai input dalam program Res2dinv. Hasil pemodelan dengan program Res2dinv kemudian diinterpretasi untuk mengetahui pola penyebaran mangan.

Interpretasi data tahanan jenis hasil inversi menggunakan beberapa data pendukung antara lain berdasarkan data penelitian terdahulu dan tabel nilai tahanan jenis pada Gambar $2^{[16]}$. Salah satu penentuan tahanan jenis mangan menggunakan metode geolistrik telah dilakukan oleh Wirayuda diperoleh nilai tahanan jenis mangan adalah $10-14 \Omega \mathrm{m}^{[12]}$. Menurut penelitian Hakim, diperoleh simpulan berdasarkan hasil penampang resistivitas 2D bahwa nilai tahanan jenis rendah $(<5 \Omega \mathrm{m})$ diduga sebagai keterdapatan mineral

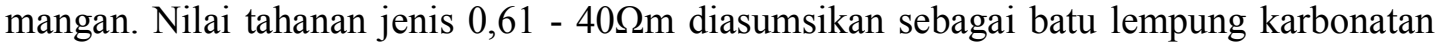
yang merupakan lingkungan terjadinya proses mineralisasi mangan ${ }^{[9]}$. Pada penelitian berskala laboratorium yang dilakukan oleh Banggut juga mendapatkan kesimpulan bahwa kisaran nilai tahanan jenis mangan di Kabupaten TTU yaitu antara $1 \Omega \mathrm{m}-32,5 \Omega \mathrm{m}{ }^{[9]}$.

Karakterisasi Geokimia dilakukan dengan pengambilan sampel bijih mangan. sampel yang sudah dikumpulkan terlebih dahulu dicuci kemudian diangin-anginkan untuk mengurangi kadar air pada permukaan. Sampel kemudian dipreparasi dengan mereduksi ukuran hingga minus 80 mesh. Sampel digerus hingga diperoleh produk dengan ukuran plus 40 mesh yang dilanjutkan dengan menggerus sampel bijih teremuk tersebut hingga diperoleh produk penggerusan yang berukuran lolos 20 mesh. Sampel yang tertampung dalam ayakan 20 mesh kembali digerus hingga minus 100 screen standar ASTM untuk melihat distribusi ukuran partikel. Selanjutnya sampel dikeringkan dengan menggunakan oven untuk menghilangkan kandungan air yang terdapat pada sampel mangan tersebut. Sampel batuan yang telah dikeringkan kemudian ditimbang sampai mencapai berat konstan (10 gram). Kemudian cuplikan sampel yang sudah halus tersebut dianalisis dengan instrument XRF untuk mengetahui komposisi kimia dan dianalisis dengan instrument XRD untuk mengetahui komposisi mineral.

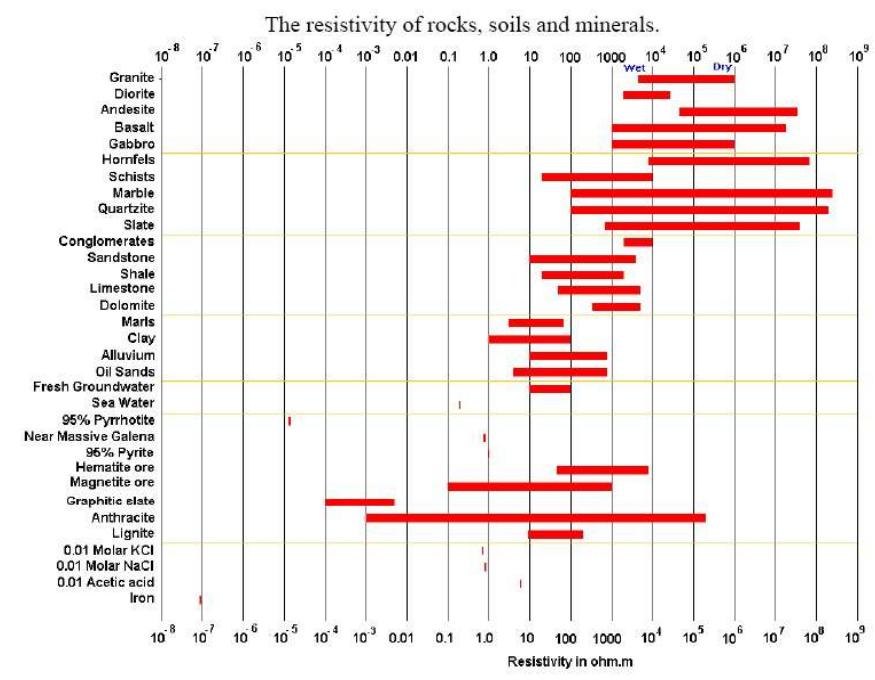

Gambar 2. Grafik acuan nilai tahanan jenis untuk beberapa batuan, tanah dan mineral ${ }^{[16]}$ 


\section{HASIL DAN PEMBAHASAN}

Pengukuran data geolistrik dari 8 lintasan dengan panjang lintasan maksimum 105 meter dan minimum 65 meter serta spasi elektroda 5 meter. Panjang lintasan berbeda-beda karena disesuaikan dengan topografi lokasi penelitian. Lintasan pengukuranrupa peta morfologi 3D dapat dilihat pada Gambar 3. Hasil inversi dengan software res2dinv diperoleh gambaran penampang dengan nilai tahanan jenis serta elevasi. Penampang setiap lintasan diberi tanda garis putus-putus merupakan lapisan yang memiliki nilai tahanan jenis yang diindikasikan merupakan lapisan mangan.

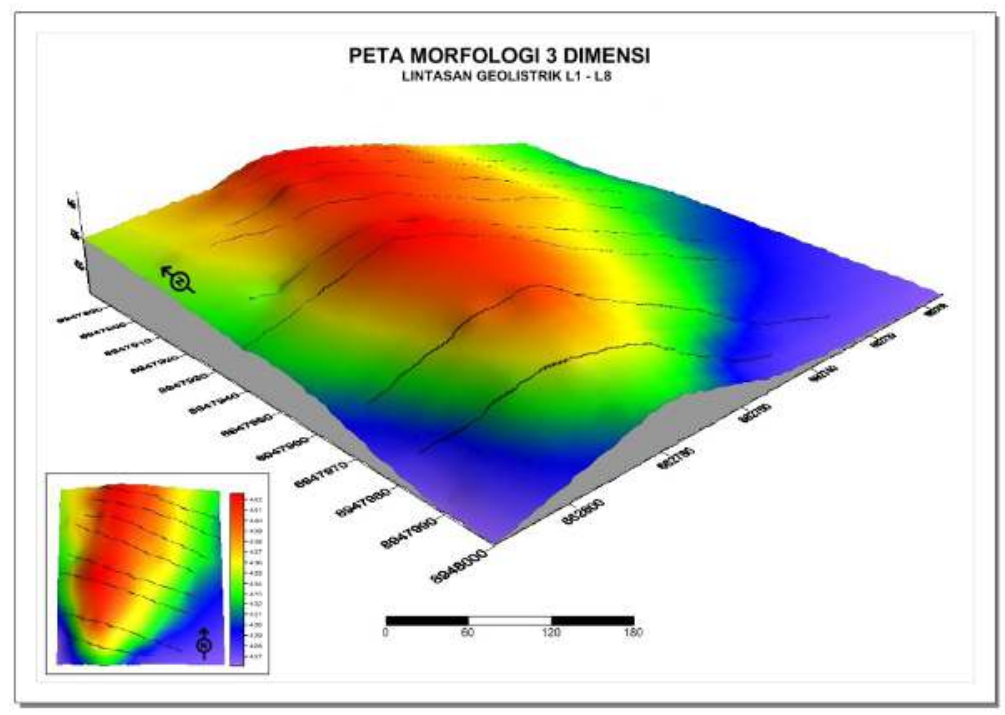

Gambar 3. Peta Morfologi 3D lintasan Geolistrik

Berdasarkan data-data pendukung dari penelitian terdahulu dan data hasil inversi, diperoleh data tahanan jenis yang diduga lapisan mangan di tiap lintasan penelitian. Tahanan jenis mangan di lokasi penelitian berkisar antara 9-30 $\Omega \mathrm{m}$ dengan kedalaman lapisan yang diduga mangan berkisar antara $1-20$ meter dari permukaan tanah. Untuk lintasan 2 tidak ditemukan adanya indikasi lapisan mangan. Selain lapisan mangan yang diduga berasosiasi dengan lapisan shale juga terdapat lapisan clay dan juga limestone.

Lintasan pertama (L1) dilakukan pengukuran dengan panjang lintasan 95 meter, 19 elektroda dengan jarak spasi 5 meter. Hasil pengolahan dengan Res2dinv yang dilakukan dengan data yang cukup banyak diperkirakan menunjukkan nilai resistivitas pada indikasi singkapan yang mengandung mangan (Mn), berkisar 9 - $30 \Omega$ m pada lintasan 1 (L1), yang tersingkap hampir merata di permukaan dengan kedalaman yang diduga $1-20 \mathrm{~m}$. Hal ini ditunjukkan dengan indikasi singkapan yang terputus seperti yang ada dalam Gambar 4a. Pada lintasan 2 (L2) diambil dengan jarak dari lintasan 1 (L1) sekitar 10 meter, panjang lintasan 95 meter, 19 elektroda dan jarak spasi 5 meter. Pada lintasan ini tidak terdapat indikasi singkapan yang mengandung mangan $(\mathrm{Mn})$, hal ini ditunjukkan dengan bekas penggalian yang telah dilakukan namun tidak ditemukannya indikasi singkapan yang mengandung mangan (Mn). 


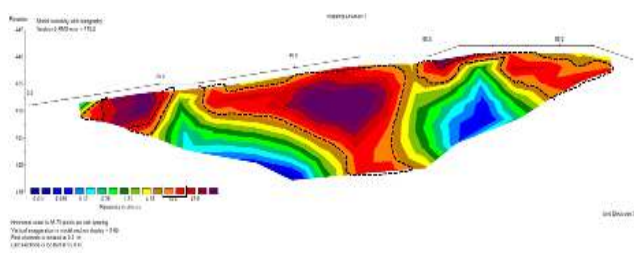

(a)

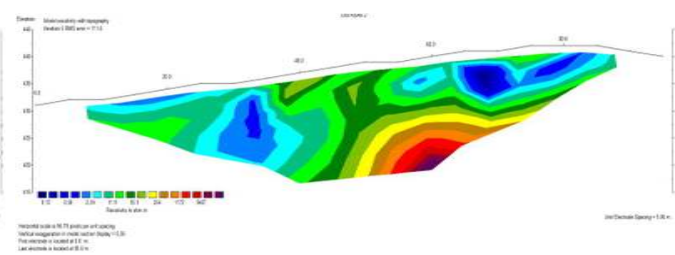

(b)

Gambar 4. (a) Penampang Lintasan Pengukuran Geolistrik L1, (b) Penampang Lintasan Pengukuran Geolistrik L2

Pada lintasan 3 (L3) yang berjarak $10 \mathrm{~m}$ dari lintasan 2, dengan panjang lintasan 105 meter, 21 elektroda dan jarak spasi 5 meter, terdapat indikasi singkapan yang mengandung mangan (Mn), dengan perkiraan nilai resistivitas 10-30 $\Omega \mathrm{m}$. Indikasi singkapan yang mengandung mangan pada lintasan 3 (L3) terletak pada titik pengukuran 10-80 m dalam penampang. Pada lintasan 4 (L4) berjarak 15 meter dari lintasan 3, dengan panjang lintasan 105 meter, 21 elektroda dan jarak spasi 5 meter, diperkirakan terdapat indikasi singkapan yang mengandung mangan (Mn) lebih banyak, pada penampang lintasan 4 (L4) berada pada titik pengukuran 10 - 75 meter. Penampang L3 dan L4 dapat dilihat pada Gambar 5.

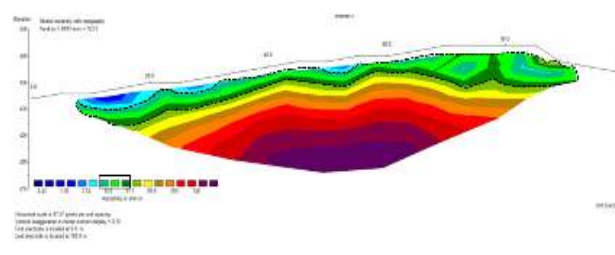

(a)

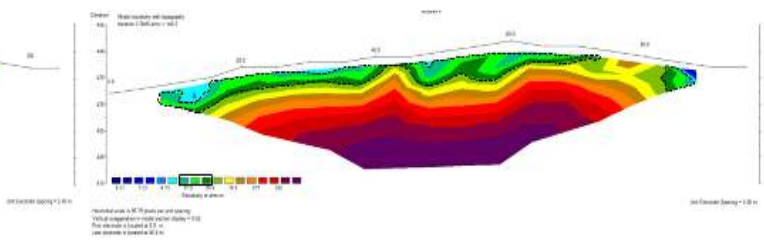

(b)

Gambar 5. (a) Penampang Lintasan Pengukuran Geolistrik L3, (b) Penampang Lintasan Pengukuran Geolistrik L4

Pada lintasan 5 (L5) berjarak 20 meter dari lintasan 4, dengan panjang lintasan 100 meter, 20 elektroda dan jarak spasi 5 meter, perkiraan nilai res2dinv menunjukan harga resistivitas indikasi singkapan yang mengandung mangan (Mn) berkisar 9-19 $\Omega \mathrm{m}$ dan tersingkap lebih kearah lembah dan juga terdapat di bukit, hal ini juga didukung terdapat bekas galian yang ada indikasi singkapan yang mengandung mangan (Mn). Pada lintasan 6 (L6) berjarak 10 meter dari lintasan 5, dengan panjang lintasan 95 meter, 19 elektroda dan jarak spasi 5 meter, perkiraan nilai res2dinv menunjukan harga resistivitas indikasi singkapan yang mengandung mangan (Mn) berkisar $9-25 \Omega \mathrm{m}$ dan tersingkap lebih kearah lembah dan juga terdapat di bukit, hal ini juga didukung terdapat bekas galian yang ada indikasi singkapan yang mengandung mangan (Mn). Penampang L5 dan L6 dapat dilihat pada Gambar 6.

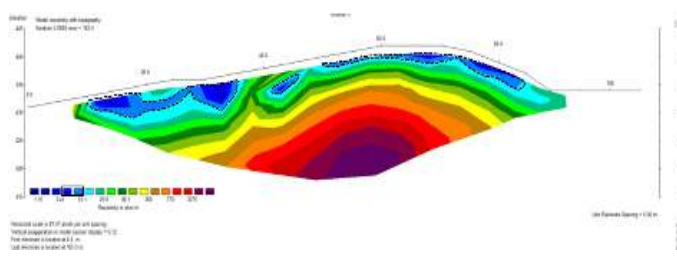

(a)

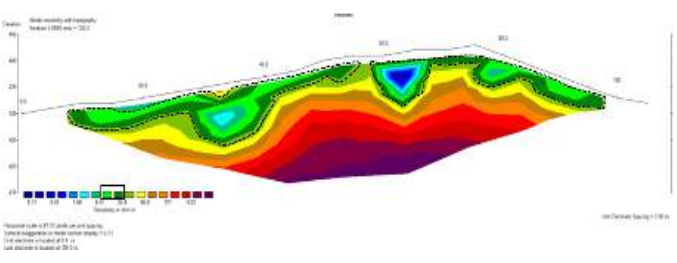

(b)

Gambar 6. (a) Penampang Lintasan Pengukuran Geolistrik L5, (b) Penampang Lintasan Pengukuran Geolistrik L6 
Pada lintasan 7 (L7) berjarak 25 meter dari lintasan 6, dengan panjang lintasan 95 meter, 19 elektroda dan jarak spasi 5 meter, diperkirakan terdapat indikasi singkapan yang mengandung mangan (Mn) lebih banyak, pada penampang lintasan 7 (L7) berada pada titik pengukuran $30-85$ meter. Perkiraan nilai res2dinv menunjukan harga resistivitas indikasi singkapan yang mengandung mangan $(\mathrm{Mn})$ berkisar $9-25 \Omega \mathrm{m}$. Pada lintasan 8 (L8) berjarak 15 meter dari lintasan 7, dengan panjang lintasan 65 meter, 13 elektroda dan jarak spasi 5 meter, perkiraan hasil nilai res2dinv menunjukan harga resistivitas indikasi singkapan yang mengandung mangan $(\mathrm{Mn})$ berkisar $10-30 \Omega \mathrm{m}$ dan tersingkap lebih kearah lembah dan juga terdapat di bukit.

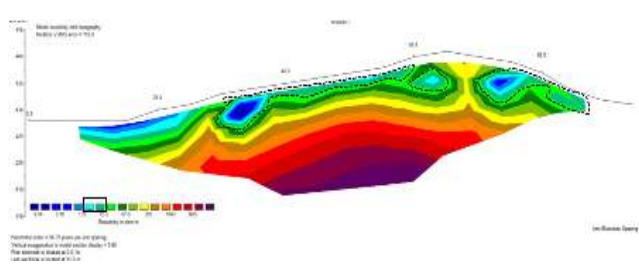

(a)

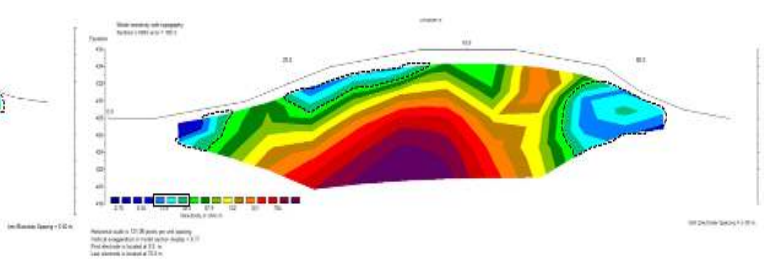

(b)

Gambar 7. (a) Penampang Lintasan Pengukuran Geolistrik L7, (b) Penampang Lintasan Pengukuran Geolistrik L8

Setelah melihat nilai tahanan jenis dan penyebaran lapisan mangan pada penampang lintasan 1 sampai lintasan 8, maka diperkirakan lintasan 3 sampai lintasan 8 bisa dikorelasi. Hal ini karena penampang tersebut terlihat adanya indikasi lapisan yang mengandung mangan.

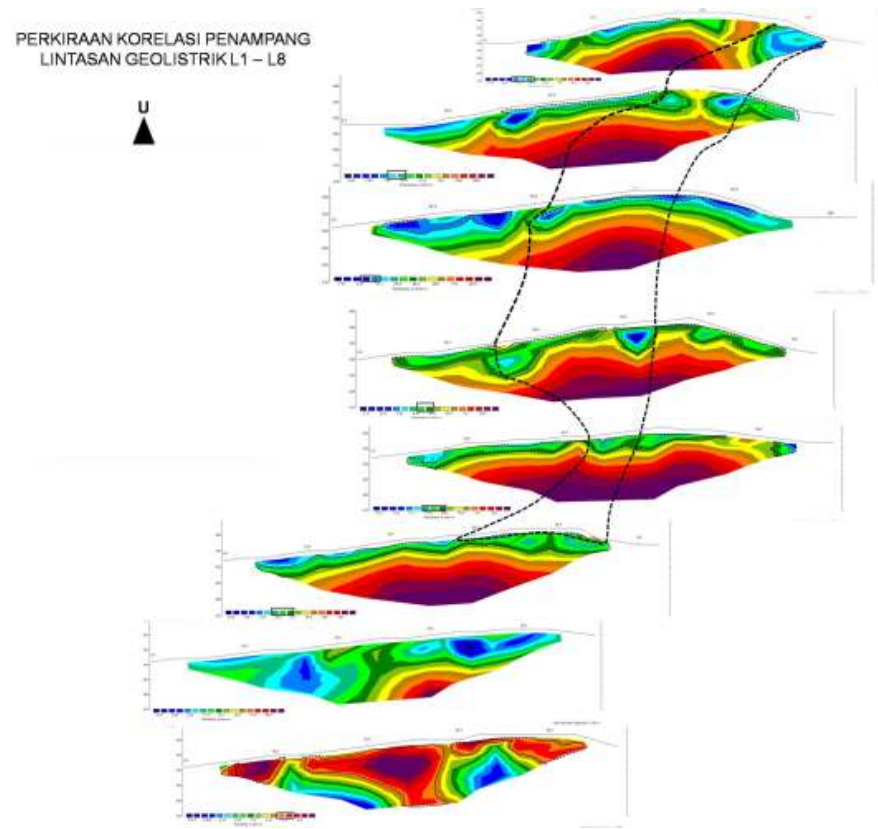

Gambar 8. Penampang perkiraan korelasi lintasan geolistrik

Karakterisasi geokimia mangan pada penelitian ini menggunakan instrumen XRF dan $\mathrm{XRD}$. Analisis menggunakan XRF untuk mengetahui komposisi unsur yang terdapat dalam sampel batuan mangan. Hasil analisis XRF menunjukkan bahwa sampel batuan mangan Oetalus mengandung Mangan (Mn), silikat (Si), kalsium (Ca), titanium (Ti), 
tembaga $(\mathrm{Cu})$, selenium $(\mathrm{Se})$ dan rhenium $(\mathrm{Re})$. Kadar masing-masing unsur dapat dilihat pada Tabel.2. Sampel mangan Oetalus memiliki kadar mangan yang cukup tinggi. Hasil analisis ini lebih tinggi dibandingkan dengan hasil analisis kadar mangan di beberapa daerah lain seperti di Sijunjung kandungan mangannya 79,70\% ${ }^{[17]}$, Bleber memiliki kandungan mangan $74,19 \%{ }^{[18]}$, Dharmasraya kandungan mangannya $60,42 \%^{[19]}$, Pasaman Barat memiliki kandungan mangan hanya $42,20 \%{ }^{[2]}$. Sedangkan untuk daerah di NTT pun kadar mangan di Oetalus lebih tinggi dibandingkan dengan di Supul, TTS yang memiliki kandungan mangan $66,43 \%{ }^{[14]}$ dan di Belu kadar mangannya $67,66 \%{ }^{[15]}$. Kadar mangan di Oetalus ini sangat potensial dan ekonomis untuk ditambang, karena kadar rata-rata ekonomis bijih mangan adalah $45 \%{ }^{[20]}$.

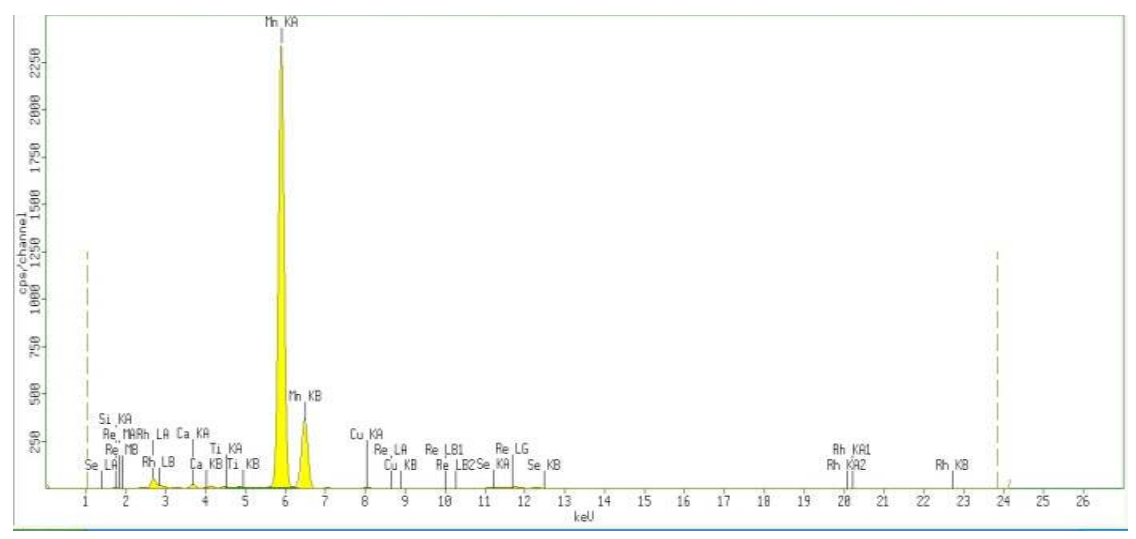

Gambar 9. Hasil analisis mangan Oetalus dalam bentuk Unsur

Tabel 2. Komposisi unsur dalam sampel mangan

\begin{tabular}{ll}
\hline Unsur & Komposisi (\%) \\
\hline $\mathrm{Mn}$ & 94,2 \\
$\mathrm{Si}$ & 3,6 \\
$\mathrm{Ca}$ & 1,26 \\
$\mathrm{Ti}$ & 0,28 \\
$\mathrm{Cu}$ & 0,22 \\
$\mathrm{Se}$ & 0,19 \\
$\mathrm{Re}$ & 0,19 \\
\hline
\end{tabular}

Analisis dengan XRD dilakukan untuk mengetahui jenis mineral yang terdapat dalam sampel batuan mangan. Data hasil pengukuran kemudian diolah dengan software Origin, hasil pengolahan data dapat dilihat pada Gambar 10. (a) Hasil difraktogram yang diperoleh merupakan pencocokan difraktogram referensi dengan difraktogram hasil uji sampel. Menurut hasil pencocokan pada Gambar 6. (a). Diketahui bahwa mineral yang terkandung dalam sampel batuan mangan dari Oetalus adalah pyrolusite $\left(\mathrm{MnO}_{2}\right)$. Pyrolusite berbentuk kristal tetragonal jarang dijumpai sebagai kristal yang sempurna di alam. Senyawa bijih mangan ini dijumpai dalam bentuk serat-serat, gumpalan-gumpalan, atau adonan menyerupai lumpur ${ }^{[2]}$. Struktur kristal $\mathrm{MnO}_{2}$ dapat dilihat pada Gambar 10. (b). 


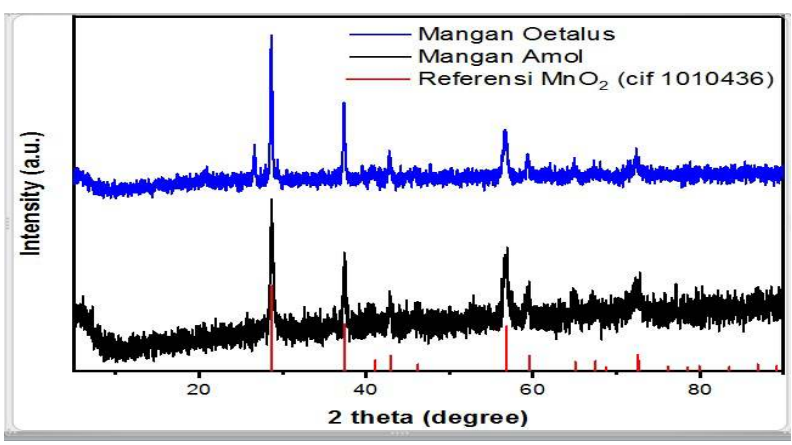

(a)

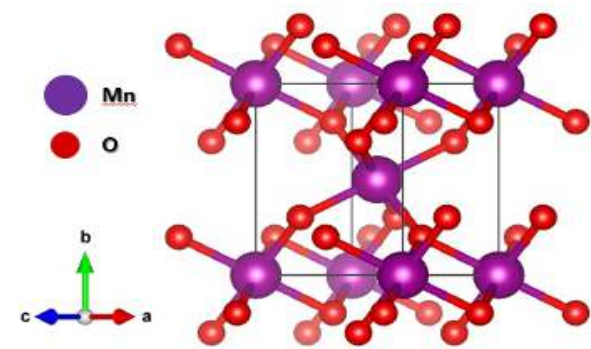

(b)

Gambar 10. (a) Hasil difraktogram mangan Oetalus dan Amol, (b) Struktur kristal $\mathrm{MnO}_{2}$

Struktur kristal $\mathrm{MnO}_{2}$ seperti Gambar 10. (b) dapat dimanfaatkan dalam berbagai aplikasi pembuatan baterai-sel kering sebagai depolarisator atau oksidator sel baterai ${ }^{[2]}$.

\section{KESIMPULAN}

Pada penelitian ini diperoleh penyebaran mineral mangan di desa Oetalus dengan nilai tahanan jenis antara 9-30 $\Omega \mathrm{m}$ dan kedalaman lapisan duga antara 1-20 meter. Mineral mangan yang terdapat di lokasi penelitian memiliki kadar mangan yang cukup tinggi yaitu $94,2 \%$ dan sangat layak digunakan dalam industri. Jenis mineral di lokasi penelitian adalah pirolusite $\left(\mathrm{MnO}_{2}\right)$.

\section{UCAPAN TERIMAKASIH}

Terimakasih kepada Kementerian Riset \& Teknologi/Badan Riset \& Inovasi Nasional atas dukungan dana melalui Hibah Penelitian Dosen Pemula tahun 2020 dengan nomor kontrak 04/UN60/LPPM/PP/2020.

\section{DAFTAR PUSTAKA}

1 Sukandarumidi. 2009. Geologi Mineral Logam. UGM. Yogyakarta.

2 Putri, P.J. 2015. Analisis Struktur Bijih Mangan Hasil Proses Sinter yang terdapat di Nagari Kiawai Kecamatan Gunung Tuleh Kabupaten Pasaman Barat. Pillar of Physics, Vol. 5, Hal. 105-112.

3 Pareira, M.J., Lima, M.F.F., \& Lima, R.M.F. 2014. Calcination and characterization studies of a Brazilian manganese ore tailing. International Journal of Mineral Processing, Hal. 26 - 30.

4 Graha, D. 1987. Batuan dan Mineral. Penerbit Nova. Bandung.

5 Tony, C. 2011. Mineral Commodity. Institute of Geological and Nuclear. Italia

6 Liu, Y., Lin, Q., Li, L., Fu, J., Zhu, Z., Wang, C., \& Qian, D. 2013. Study On Hydrometallurgical Process and Kinetics Of Manganese Extraction From Low-Grade Manganese Carbonate Ores. International Journal of Minning Science and Tecnology, Hal. 567-571.

7 Damtoro. 2007. Geofisika. http://www.geolistrik.com.

8 Rosana, M.F. 2007. Laporan Pemetaan Geologi dan Survey Geofisika Bahan Galian $\mathrm{Pb}$ dan $\mathrm{Zn}$. Jurusan Geologi Universitas Padjadjaran. Bandung

9 Wirayuda, H. 2013. Analisis Deposit Mineral Mangan (Mn) di Desa Pucung Kecamatan Eromoko Kabupaten Wonogiri. Skripsi S1 Jurusan Fisika Universitas Negeri Semarang. 
10 Banggut, E. 2011. Penentuan Resistivitas Batuan Mangan di daerah Kabupaten TTU Menggunakan Metode Geolistrik dalam Skala Laboratorium. Skripsi S1 Jurusan Fisika Universitas Nusa Cendana. Kupang.

11 Hakim, M., Syamsudin., \& Makhrani. 2015. Identifikasi Sebaran Mineral mangan di Bawah Permukaan Menggunakan Metoda Geolistrik Tahanan Jenis Konfigurasi Wenner - Schlumberger di Kabupaten Timor Tengah Utara Provinsi Nusa Tenggara Timur. Repository UNHAS. Makassar.

12 Sufriadin. 2015. Studi Mineralogi dan Geokimia Endapan Mangan Daerah Paluda Kabupaten Barru, Sulawesi Selatan. Proceeding Seminar Nasional Kebumian ke-8 (pp.202-210). Department Geologi-UGM. Yogyakarta.

13 Panjaitan, R.R. 2011. Kajian Pemanfaatan Batu Mangan/Senyawa Mangan Dalam Industri. Berita Litbang Industri, Volume XI VII No 2. pp 45-53.

14 Naiola, M.N. 2015. Studi Genesis Endapan Mangan Daerah Supul Kecamatan Kuatnana Kabupaten Timor Tengah Selatan Propinsi Nusa Tenggara Timur. Eprints UPN Veteran Jogjakarta. Jogjakarta.

15 Da Costa, A. 2016. Studi Genesa Endapan Bijih Mangan di Daerah Lamaksenulu dan Sekitarnya Kecamatan Lamaknen Kabupaten Belu Provinsi Nusa Tenggara Timur. Repository UGM. Yogyakarta.

16 Looke, M.H. 2004. Tutorial: 2-D and 3-D Electrical Imaging Surveys. Goetomo Software. Penang, Malaysia.

17 Mustofa, dkk. 2018. Analisis Pengaruh Proses Sintering Terhadap Struktur Bijih Mangan Yang Berasal Dari Nagari Aie Ramo, Kecamatan Kamang Baru, Kabupaten Sijunjung. Jurnal Fisika Unand, Vol. 7, No.3.

18 Ansori, C. 2010. Potensi Genesis Mangan di Kawasan Kars Gombong Selatan Berdasarkan Penelitian Geologi Lapangan Analisis Data Induksi Polarisasi dan Kimia Mineral. Buletin Sumber Daya Geologi, Vol.5 No.2.

19 Kisman, Bambang P., \& Edya P. 2016. Prospeksi Mangan di Kecamatan Timpeh, Kabupaten Dharmasraya, Provinsi Sumatera Barat. Prosiding Kelompok Penyelidikan Mineral. Pusat Sumber Daya Geologi.

20 Arief, R., Suhandi., \& Putra, C. 2011. Penelitian Bahan Galian Lain Dan Mineral Ikutan Pada Wilayah Pertambangan Di Kabupaten Minahasa Utara, Provinsi Sulawesi Utara. Prosiding Hasil Kegiatan. Kelompok Penyelidikan Konservasi dan Unsur Tanah Jarang. Pusat Sumber Daya Geologi. 